\title{
Influence of Teachers' Characteristics on Their Attitude Towards the Integration of ICT in Mathematics Instruction in Primary Schools Mathematics Instruction in Nakuru East Sub-County - Kenya
}

\author{
Eunice Chebett Rotich Prof. B.N. Githua Dr. J.K. Ng'eno \\ Department of Curriculum, Instruction and Educational Management, Egerton University Njoro Main Campus
}

\begin{abstract}
There is pressure placed on the Government of Kenya and the private sectors in the country to strive and compete in the digital world in their operations. In particular, the use of Information Communication Technology (ICT) in institutional operations in Kenya is significant, especially in the education sector. Teachers' lack of ICT skills is the main challenge to integration of ICT in the instructional processes in schools. This study sought to find out whether teachers characteristics influence their attitude towards ICT integration in their classroom practice. Teachers' characteristics entailed qualification and teachers' computer competencies, experiences and computer training. The study investigated the influence of teachers' characteristics on their attitude towards integration of ICT in primary school mathematics instruction in Nakuru Town East Sub-county of Nakuru County, Kenya. In the study, a Correlational research design was applied. A total of 1364 primary school teachers in Nakuru Town East Sub-County, was the target population in the study. The accessible population were all the mathematics teachers from the public primary schools from which a sample size of 140 participated in the study. Simple random sampling was used to select five divisions and proportionate stratified sampling was used to select participating schools and teachers in the study. The head teachers in the participating schools were selected purposefully as part of the teachers to provide information about ICT resources. The data was collected using a self-report questionnaire. The experts in the department of curriculum Instruction and Educational Management validated the instrument. The tool was pilot tested in schools in the neighboring county which had similar characteristics as the study are. The reliability of the research instrument was found to be 0.906 which was within acceptable threshold for social science research. Descriptive (frequency distributions, means, and percentages) and inferential statistics (correlation and regression analysis) were used to analyze the collected data with the help of SPSS program version 26. The hypothesis was tested at 0.05 Alpha $(\alpha)$ level of significance. The study established the existence of a strong statistically significant positive relationship $(r=0.879, \mathrm{p}<0.05)$ between teacher characteristics and attitude towards the integration of ICT in mathematics instruction. The study established that teacher characteristics (Teaching experience, qualification, and ICT training) were strong predictors of teacher attitude towards integration of ICT in mathematics instruction $(\beta=0.155, p<0.05, \beta=0.247, p<0.05$ and $\beta=0.465, p<0.05)$ respectively. The findings may help in informing policymakers and teacher trainers to include ICT in both on the job and out of job teacher training programs.
\end{abstract}

Keywords: Attitude, Information Communication Technology, teacher characteristics and integration of ICT, and mathematics instruction

DOI: $10.7176 / \mathrm{JEP} / 11-36-11$

Publication date: December $31^{\text {st }} 2020$

\section{Background to the Study}

World Summit on the Information Society (WSIS) held in Geneva 2003, and Tunis 2005 resulted in clear commitments by governments to foster the achievement of inclusive information society. Promotion of Information and Communication Technology (ICT) use towards internationally agreed 2030 agenda for Sustainable Development enhance inclusive information society (Canazza, 2018). The United Nations Educational, Scientific and Cultural Organization (UNESCO) and the International Telecommunication Union (ITU) have been at the forefront encouraging the coupling of the powerful influence of the Information and Communication Technologies (ICTs) in efforts to achieve 2015 internationally agreed Sustainable Development Goals (SDGs).

The WSIS plan of action captured the goals, which seek to address new challenges of the information society at national, regional and international levels (world summit on information society, 2003). The ten identified targets by WSIS were set to be attained by 2015 , two of which are related to education. Their second target was on connecting all primary schools to information and communication technology (ICT), and the seventh one was on adapting all primary schools' curriculum to meet the challenges of the information society (Partnership on Measuring ICT for Development, 2011).

ICT continues to advance in western and Asian countries, African countries are still striving to implement ICT policies, and these widen the digital and knowledge divides (Reffel \& Whitworth, 2010). A new partnership 
for African Development (NEPAD) was initiated to address challenges facing Africa and has identified ICT infrastructure as a priority area for inducement of conditions for sustainable development (NEPAD, 2012). NEPAD identified six areas of high priority. Among these was the NEPAD e-schools programme whose objective is to integrate ICT in the delivery of education curriculum at primary and secondary school levels to improve access, quality and equity in education among its member states Kenya included. The implementation plan envisaged the coverage of primary schools in ten years (Michura, 2019).

According to Hockly \& Dudeney (2018), the vision 2030 envision to have globally competitive quality education training and research for sustainable development achieved through reducing literacy by increasing access to education. Other goals are capitalizing on knowledge in Science Technology and Innovations (ST\&I). To ensure that it is on the right track in realizing its economic objectives, the government of Kenya embraced an ambitious project of introducing one laptop per child in standard one in the year 2014 (MOEST, 2010). The Kenya Government through the Ministry of Education Science and Technology was credited with the responsibility of providing a quality education that empowers learners to competitively function within a highly integrated technologically oriented information-based global economy. To achieve this Kenya is guided by the following legal frameworks: National ICT policy 2006 on improving livelihoods of Kenyans by ensuring the availability of accessible, efficient, reliable and affordable ICT services; Constitution of Kenya 2010; Kenya vision 2030 blue print through Medium Term Plan (MTPs) and Kenya Institute of Curriculum Development (KICD) act 2013.

Integration of ICT in teaching/learning process aims at utilizing ICT to increase access to education, allow multi-sensory learning, boost students self- confidence and stimulate sensory and cognitive curiosity, promote learner-centered approach, active, integrative, creative, evaluative and enhance different learning pathways (Intel ,2012). ICT integration is built on four pillars. Namely: overall view/policy of education being relevant; teachers' expertise; availability of digital learning materials; and adequate ICT infrastructure (MOEST, 2013). According to Lawrence \& Tar, (2018), the four pillars of ICT integration describe the basic elements-the building blocks-that must be in balance with one another before teachers can use ICT effectively and derive the benefits that they want that is to use ICT to provide. When teachers use technology strategically, they can provide greater access to mathematics for all students. Teachers integrate ICT in teaching and learning in mathematics because of its desirability, automation, capacity and range (Ayiema, Mwoma, \& Ouko, 2019).

According to Communication Commission of Kenya (2013), the current Kenya government promised all public primary schools one laptop for every class one pupil by the year 2017. At the moment, the Ministry of Education Science and Technology has allocated funds for improving infrastructure (access to electricity and building computer labs), and equipping was done (ICT Authority Board, 2016). Some of the obstacles to the integration of ICTs in teaching and learning are intrinsic to the teacher, and its extent is not known. It, therefore, compelled the researcher to set out and investigate whether primary school teachers are ready to embrace ICT integration in teaching. The researcher intends to find out the Influence of teachers' Characteristics on their attitude to integrate ICT in primary school mathematics instruction.

Teacher's attitudes play a prominent role in education interaction as well as mathematic instructional choices and are fundamental for successful integration and usefulness of ICT into mathematics instruction (Dogan, 2010). Teachers' positive attitudes towards the use of ICT in teaching and the availability of the necessary resources were important determinants to facilitate the use of technology in teaching mathematics in the primary school classroom (McAlister, Dunn \& Quinn, 2005). Teachers' positive attitude towards ICT is expected to foster ICT integration in mathematics instruction (Andoh, 2012). Research has shown that teachers' attitudes towards technology influence their acceptance of the usefulness of technology and its integration into teaching (Mulwa, Kyalo, Bowa and Mboroki, 2011).

According to the study by Ayub, Bakar \& Ismail (2015), new teachers were highly skilled with technology more than older teachers who did not incorporate ICT in their teaching. In a survey of almost 3000 teachers, they argued that the quality of ICT integration was related to the years of teaching service. However, Granger, Morbey, Lotherington, Owston, and Wideman (2002) conducted a qualitative survey on factors contributing to teachers' successful implementation of ICT in Canada. They interviewed 60 respondents from 12 schools. The findings found no relationship between teachers' teaching experience and experience in the use of ICT, implying that teachers' ICT skills and successful implementation are complex and not a precise predictor of ICT integration. Teachers' computer experience relates positively to their computer attitudes. The more experienced teachers have with computers, the more likely that they will show positive attitudes towards integration in the classroom (Van Braak, Tondeur \& Valcke, 2004).

Teachers' computer competence is a significant predictor of integrating ICT in teaching; Evidence suggests that the majority of teachers who reported negative or neutral attitudes towards the integration of ICT into teaching and learning processes lacked knowledge and skills that would allow them to make "informed decisions" (Bordbar,2010).

The study is guided by the Davies technological acceptance model (TAM) (Davis, 1989) and Ajzen's theory of planned behavior (TPB) (Ajzen, 1991). The necessary ground of TAM, as developed by Davies (1989), is to 
explain computer usage behavior. TAM specifies the causal linkages between two determinants of computer acceptance that is capable of explaining user behavior across a broad range of technologies perceived use (P U) and perceived ease of use (P E U) and user's attitude (A), behavioral intention (B I) and actual computer usage.

\subsection{Statement of the Problem}

Digital literacy is presumed to play a significant role in our future lives. Technology empowers teachers and the challenge for education is to develop technological skills among teachers to enable them to deliver content effectively and efficiently in a school setting. Primary schools have to be compatible with the ever-expanding knowledge and be equipped with the technology to deal with this knowledge. Information communication technologies such as radio, television, and telephony, as well as computers and the internet, have proven as potentially powerful tools that teachers can use for educational change and reform. The difference to be realized if teachers can completely integrate ICTs in teaching without any obstacles. Teachers' characteristics may influence some of the challenges in the integration of ICTs in teaching. However, it is not clear to what extent the teachers' characteristics may alter the integration of ICT in the education of primary schools in the Nakuru East sub-county. It was, therefore, the wish of the researcher to investigate if primary school teachers' characteristics influence their attitude to integrate ICT in primary school mathematics instruction in Nakuru East Sub-county, Kenya.

\subsection{Objective of the Study}

To establish the influence of teachers' characteristics on their attitude towards the integration of ICT in mathematics instruction.

\subsection{Hypothesis of the Study}

Ho1: There is no statistically significant influence of teachers' characteristics on their attitude to integrate ICT in mathematics instruction.

\section{Research Methodology}

This study used a correlational research design. The study was carried out in Nakuru East Sub-County of Nakuru County. The population of the study was all teachers in public primary schools in Nakuru East Sub-county of Nakuru County. There are a total of 1364 primary school teachers in five divisions, with a total of 62 public primary schools (Nakuru County teachers service Management System,2018). The target population was all public primary school teachers in the sub-county. The accessible populations were all public primary school mathematics teachers. There were 1040 females and 324 male teachers in the whole sub-county. This study adopted stratified random sampling and purposive sampling to select a sample size of 140 participants from the 1364 mathematics teachers (Williamson, 2018). The researcher used the list of schools at Nakuru Town East Sub- County director's management office as the sampling frame. The head teachers in the participating schools were purposively selected as part of the teachers to provide information about ICT resources. The teachers in any given school were further classified by gender and qualification and using the attendance register in the head teachers' office as the sampling frame.

The data were collected through structured questionnaires which were administered to the teachers at the place of work. A questionnaire was selected because it provides a high degree of data standardization and adoption of generalized information amongst any population (Fisher, Mann, Cronk, Shields, Klug \& Ramaswamy,2016). The data collected were analyzed using both descriptive and inferential statistics. The hypothesis was tested at the 0.05 Alpha $(\alpha)$ level. The data were analyzed using a computer program, the Statistical Package for Social Science (SPSS) version 26.

\section{RESULTS AND DISCUSSIONS}

\subsection{Descriptive Statistics of Teacher Characteristics}

The objective of the research study was to establish the influence of teacher characteristics on their preparedness to integrate ICT in mathematics instruction while the null hypothesis of the study stated that 'There is no statistically significant influence of teachers' characteristics on their attitude to incorporate ICT in mathematics instruction'. Descriptive statistical analysis was used to analyze elements of teacher Characteristics that included: Teachers' qualifications, experience and ICT training. A Likert scale was used in the study design, five represented frequently, four served occasionally, three represented sometimes, two represented rarely, and one described never, therefore never (1) was minimum (Min), often (5) was maximum (Max). Table 1 shows the mean scores of the elements of Teacher's qualification to computer software in teaching and learning mathematics. 
Table 1: Elements of Teachers Qualification on Use of Computer Software in Teaching and Learning

\begin{tabular}{|c|c|c|c|c|c|}
\hline Elements of Teachers Qualification & $\mathrm{N}$ & Min & Max & Mean & SD \\
\hline Word processor e.g. Ms. Word & 140 & 1 & 5 & 3.06 & 1.274 \\
\hline Data bases e.g. Ms. Access & 140 & 1 & 5 & 2.84 & 1.227 \\
\hline Spreadsheet e.g. excel & 140 & 1 & 5 & 2.99 & 1.217 \\
\hline Presentation Software, e.g., prepare drawings, create a presentation, edit and save & 140 & 1 & 5 & 2.76 & 1.185 \\
\hline Internet e.g. set internet & 140 & 1 & 5 & 3.29 & 1.306 \\
\hline e-mailing e.g. create email, identify and open a mailbox & 140 & 1 & 5 & 3.19 & 1.290 \\
\hline \multicolumn{4}{|l|}{ Overall mean score and overall SD } & 3.02 & 1.250 \\
\hline
\end{tabular}

Source: Researcher (2019)

According to the findings of the study in Table 1, most elements had their mean scores approximately 3 (sometimes) showing that most respondents had responses inclined to sometimes in most the aspects of teacher's qualification to Computer Software in Teaching and Learning. This could be attributed to the strategies used by the ministry of education to train teachers on the use of computer software in teaching and Learning. Table 2 shows the mean scores of the elements of Teacher's experience in use of computers in teaching and learning mathematics. Table 2: Elements of Teachers Experience in use of Computers in Teaching and Learning Mathematics

\begin{tabular}{|c|c|c|c|c|c|}
\hline & $\mathrm{N}$ & Min & Max & Mean & SD \\
\hline I use a computer for learning or practicing skills & 140 & 1 & 5 & 2.55 & 1.048 \\
\hline Use computer as a tool & 140 & 1 & 5 & 2.79 & 1.128 \\
\hline Use to prepare lessons & 140 & 1 & 5 & 2.51 & 1.178 \\
\hline To communicate with colleagues & 140 & 1 & 5 & 3.05 & 1.140 \\
\hline To process text & 140 & 1 & 5 & 2.81 & 1.092 \\
\hline \multicolumn{4}{|c|}{ Overall mean score and overall SD } & 2.74 & 1.117 \\
\hline
\end{tabular}

Source: Researcher (2019)

According to the mean scores of the elements of Teacher's experience in use of computers in teaching and learning mathematics in Table 2, most elements had their mean score approximately 3 (sometimes) showing that most teachers had responses inclined to sometimes in most the aspects of teacher's experience in use of computers in teaching and learning. This could be attributed to the teachers' lack of experience in the use of computer software in teaching and Learning augmented by the study done by Wanjala, (2016) on Information Communication Technology Pedagogical integration in mathematics instruction among teachers in secondary schools in Kenya where the results of the study established that teachers lack of experience in the use of computer software in teaching and Learning. Table 3 shows the mean scores of the elements of Teacher's ICT training in use of computers in teaching and learning mathematics.

Table 3: Elements of Teachers ICT Training in the use of Computers in Teaching and Learning Mathematics

\begin{tabular}{llllll}
\hline & $\mathrm{N}$ & Min & Max & Mean & SD \\
\hline To find digital learning resources & 140 & 1 & 5 & 2.84 & 1.001 \\
To analyze students achievement performance data. & 140 & 1 & 5 & 3.06 & 1.207 \\
To make presentation create graphics & 140 & 1 & 5 & 2.40 & 1.098 \\
\hline & Overall mean score and overall SD & & & 2.77 & 1.100 \\
\hline
\end{tabular}

Source: Researcher (2019)

Based on the mean scores of the elements of Teacher's ICT training in use of computers in teaching and learning mathematics in Table 14, mathematics teachers were sometimes trained to use computers in teaching and learning could analyze student's achievement performance data (Approximate mean score of 3). Additionally, teachers trained in the use of computers in teaching and learning rarely make a presentation to create graphics for teaching and learning (Approximate mean score of 3) experience in the use of computers in teaching and learning. Rani \& Anisha, (2018) reported that teachers use of ICT use in primary and secondary schools' mathematics emphasis on improving the quality of subject teaching and learning. Table 3 shows the mean scores of the elements of attitude towards the use of computers in teaching and learning mathematics. 
Table 4: Elements of Attitude towards the Use of Computers in Teaching and Learning Mathematics

\begin{tabular}{|c|c|c|c|c|}
\hline \multirow{2}{*}{$\begin{array}{l}\text { Elements of Attitude } \\
\text { I feel confident that I can select appropriate software in my mathematics lessons }\end{array}$} & \multicolumn{4}{|c|}{ N MinMaxMeanSD } \\
\hline & 1401 & 5 & 3.20 & 1.026 \\
\hline I feel confident that I can use the internet in my lessons to meet specific learning goals & 1401 & 5 & 3.63 & .884 \\
\hline I fee & 1401 & 5 & 3.35 & .974 \\
\hline I fee & 1401 & 5 & 2.59 & 1.187 \\
\hline about ICT & 1401 & 5 & 2.51 & 1.160 \\
\hline Teac & 1401 & 5 & 3.84 & 1.015 \\
\hline |Teachers lack basic knor & 1401 & 5 & 3.65 & 1.079 \\
\hline A computer is an available tool for te & 1401 & 5 & 3.43 & 1.259 \\
\hline \multicolumn{5}{|l|}{ Overall mean score and overall SD } \\
\hline
\end{tabular}

\section{Source: Researcher (2019)}

According to the results of the study in Table 2, the respondents agreed that they feel confident when using internet in their lessons to meet specific learning goals, teacher's lack in-service training and necessary knowledge/skills for ICT integration in teaching and learning with mean scores inclined towards 4 (Agree). This agree with the study done by Adukaite, VanZyl, Er \& Cantoni, (2017) on teacher perceptions on the use of digital gamified learning in tourism education where the results of their study reveal that teachers exuded confidence when using internet in their lessons to meet specific learning objectives. Moreover, the respondents were neutral that they feel confident to select appropriate software in their mathematics lessons, use presentation software in their classes, will not master advanced ICT skills, and sometimes get nervous just thinking about ICT with mean scores inclined towards 3 (Neutral).

To test the hypothesis of the study that there is no statistically significant influence of teachers' characteristics on their attitude to incorporate ICT in mathematics instruction, correlation and regression analyses were used.

\subsection{Correlation of Teacher Characteristics and Attitude towards Integration of ICT in Mathematics Instruction}

The study used Pearson moment correlation and Spearman's rank correlation coefficient to establish the strength, direction, and significance of the relationship that exists between teacher characteristics and attitude towards the integration of ICT in mathematics instruction. Table 5 shows the correlation between teacher's characteristics and attitude towards integration of ICT in mathematics instruction.

Table 5: Correlation between Teacher Characteristics and Attitude towards Integration of ICT in Mathematics Instructions

\begin{tabular}{lll}
\hline Teaching experience & & Teachers Attitude \\
& Pearson Correlation & $.687^{* *}$ \\
Qualification & Sig. (2-tailed) & .000 \\
& $\mathrm{~N}$ & 140 \\
& Spearman's rank correlation & $.750^{* *}$ \\
ICT training & Sig. (2-tailed) & .000 \\
& $\mathrm{~N}$ & 140 \\
& Spearman's rank correlation & $.759 * *$ \\
Teachers Characteristics & Sig. (2-tailed) & .000 \\
& $\mathrm{~N}$ & 140 \\
& Pearson Correlation & $.879 * *$ \\
& Sig. (2-tailed) & .000 \\
\hline
\end{tabular}

** Correlation is significant at the 0.05 level (2-tailed).

Source: Researcher (2019)

Based on Table 5, the results of the study revealed that there was a strong statistically significant positive relationship $(r=0.687, \mathrm{p}<0.05, r=0.750, \mathrm{p}<0.05$ and $r=0.759, \mathrm{p}<0.05)$ between teaching experience, qualification, ICT training and attitude towards integration of ICT in mathematics instruction respectively. Moreover, the study further revealed the overall existence of a strong statistically significant positive relationship $(r=0.879, \mathrm{p}<0.05)$ between teacher characteristics and attitude towards the Integration of ICT in Mathematics Instruction. Therefore, this confirms the positive influence of teacher characteristics on attitude towards the Integration of ICT in Mathematics Instruction. The results of the study in Table 3 conform with the findings of study done by Chemwei, (2019) on relationship between teacher educators' attitude towards computers and their level of ICT integration in instruction in primary teacher training colleges in Kenya where they established that teacher educators' characteristics significantly influence the attitude towards computers and their level of ICT integration in instruction in Kenya. 


\subsection{Regression Analysis}

The study further used linear regression analysis to determine the influence of teacher characteristics on their attitude towards the integration of ICT in mathematics instruction. Table 6 shows the results of linear regression analysis determining the influence of teacher characteristics on their attitude towards integration of ICT in mathematics instruction.

Table 6: Model Summary on Contribution of Variance teachers' Characteristics to their Attitude in ICT Use

\begin{tabular}{lllll}
\hline Model & R & R Square & Adjusted R Square & SD \\
\hline 1 & $.893 \mathrm{a}$ & .797 & .793 & .20486 \\
\hline
\end{tabular}

a. Predictors: (Constant), ICT training, Teaching experience, Qualification

b. Dependent Variable: Teachers attitude

According to the regression results in Table 6, the linear regression model specifies that teacher characteristics (Teaching experience, qualification, and ICT training) accounted for $79.7 \%\left(\mathrm{R}^{2}=0.797\right)$ of teacher attitude towards the integration of ICT in mathematics instruction. Therefore $20.3 \%$ of the variance in teacher attitude towards the integration of ICT in mathematics instruction was explained by other factors, not in the study. ANOVA analysis was used to test the suitability of the linear regression model in the use of teacher characteristics to predict their use in mathematics classrooms as shown in Table 7.

Table 7: ANOVA analysis

\begin{tabular}{lllllll}
\hline Model & & Sum of Squares & Df & Mean Square & F & Sig. \\
\hline 1 & Regression & 22.476 & 3 & 7.492 & 178.524 & $.000 \mathrm{~b}$ \\
& Residual & 5.707 & 136 & .042 & & \\
& Total & 28.184 & 139 & & & \\
\hline
\end{tabular}

a. Dependent Variable: Teachers attitude

b. Predictors: (Constant), ICT training, Teaching experience, Qualification

The F statistic (178.524) shows the fitness of the linear regression using ANOVA for regression model, which means teacher characteristics is a significant predictor of teacher attitude towards the integration of ICT in mathematics instruction.

Table 8: Unstandardized beta Coefficients for the Teachers Characteristics Regressed on Attitude towards Integration of ICT in Mathematics Classrooms

\begin{tabular}{|c|c|c|c|c|c|}
\hline \multirow[b]{2}{*}{ Model } & \multicolumn{2}{|c|}{ Unstandardized Coefficients } & \multicolumn{2}{|c|}{ Standardized Coefficients } & \multirow[b]{2}{*}{ Sig. } \\
\hline & $\mathrm{B}$ & Std. Error & Beta & $\mathrm{T}$ & \\
\hline 1 (Constant) & .544 & .184 & & 2.963 & .004 \\
\hline Teaching experience & .155 & .036 & .215 & 4.264 & .000 \\
\hline Qualification & .247 & .031 & .423 & 7.961 & .000 \\
\hline ICT training & .465 & .057 & .407 & 8.192 & .000 \\
\hline
\end{tabular}

a. Dependent Variable: Teachers attitude

Source: Researcher (2019)

The unstandardized beta coefficients in Table 8 indicate that teaching experience, qualification and ICT training $(\beta=0.155, p<0.05, \beta=0.247, p<0.05$ and $\beta=0.465, p<0.05)$ respectively were a strong predictors of teacher attitude towards integration of ICT in mathematics instruction. Therefore, the linear regression results in Table 8 indicate that teacher characteristics (Teaching experience, qualification, and ICT training) have a statistical positive significant influence on teacher attitude towards the integration of ICT in mathematics instruction.

Consequently, the null hypothesis $(\mathrm{H} 0=0)$ which stated that 'there is no statistically significant influence of teachers' characteristics on their attitude towards integration of ICT in mathematics instruction' was rejected, and the alternative hypothesis $(\mathrm{H} 1 \neq 0)$ which states that 'there was statistically significant influence of teachers' characteristics on their attitude towards integration of ICT in mathematics instruction was accepted. This suggests that teacher's attitude towards the integration of ICT in mathematics instruction is enhanced by teacher characteristics of teaching experience, qualification and their ICT training. The findings of the study agree with study done by (Hooker, 2017) on the implementation of the" Strengthening Innovation and Practice in Secondary Education Initiative" for the Preparation of Science, Technology, Engineering and Mathematics(STEM) Teachers in Kenya to Integrate Information and Communication Technology (ICT) in Teaching and Learning. The findings of the study agree with the findings of study done by Marbán and Mulenga, (2019) on pre-service primary teachers' teaching styles and attitudes towards the use of technology in mathematics classrooms where they established that teacher's attitude had significantly influence the use of technology in mathematics classrooms.

\section{Interpretation of Multiple Regression Model Results.}

The results in Table 6 shows that

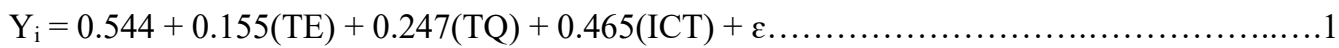

Where $\mathrm{Y}_{\mathrm{i}}=$ Teachers attitude towards the integration of ICT in mathematics instruction, $\mathrm{TE}=$ Teacher 
Experience, $\mathrm{TQ}=$ Teacher Qualification, $\mathrm{ICT}=$ Information Communication Technology training and $\varepsilon=$ Error term

This means that when there is a unit increase in teaching experience, qualification, and ICT training, teacher attitude towards the integration of ICT in mathematics instruction will increase by $0.155,0.27$ and 0.465 units respectively. The linear regression model specifies that the teacher characteristics have a positive influence on teacher attitude towards the integration of ICT in mathematics instruction.

\section{Conclusion and Recommendations}

The study concludes that teacher characteristics (Teaching experience, qualification, and ICT training) have a statistically significant influence on teacher's attitudes towards the integration of ICT in mathematics instruction.

\subsection{Institutional Recommendations}

Public primary school management should ensure the training of all mathematics teachers on necessary computer skills to enhance their attitude towards the integration of ICT in mathematics instruction.

\subsection{Policy Recommendations}

The national government through the MOE should come up with policies inclined towards the introduction of inservice training and necessary knowledge/skills for ICT integration among teachers of mathematics in all public primary schools in the country to enhance their attitude and preparedness to integrate ICT in mathematics instruction

\subsection{Recommendations for Further Research}

This research selectively captured the influence of public primary school teachers' characteristics (Teaching experience, qualification, and ICT training) on their attitude towards the integration of ICT in mathematics instruction to integrate ICT in mathematics instruction in Nakuru East sub-county only. Therefore, further research can be done to capture other public primary schools in other counties to establish whether the findings are similar.

\section{References}

Adukaite, A., van Zyl, I., Er, Ş. and Cantoni, L., 2017. Teacher perceptions on the use of digital gamified learning in tourism education: The case of South African secondary schools. Computers \& Education, 111, pp.172190.

Ajzen, I., 1991. The theory of planned behavior. Organizational behavior and human decision processes, 50(2), pp. $179-211$

Ayiema, J.O., Mwoma, T. and Ouko, H., 2019. Determinants of Teachers' Use of Instructional Resource in Teaching Pre-Primary School Science and Mathematics Activities in Machakos County, Kenya. International Journal of Current Aspects, 3(II), pp.159-185.

Ayub, A.F.M., Bakar, K.A. and Ismail, R., 2015, October. Factors predicting teachers' attitudes towards the use of ICT in teaching and learning. In AIP Conference Proceedings (Vol. 1682, No. 1, p. 030010). AIP Publishing LLC.

Bordbar, F., 2010. English teachers' attitudes toward computer-assisted language learning. International Journal of Language Studies, 4(3).

Buabeng-Andoh, C., 2012. An exploration of teachers' skills, perceptions and practices of ICT in teaching and learning in the Ghanaian second-cycle schools. Contemporary Educational Technology, 3(1), p.36.

Canazza, M.R., 2018. The Internet as a global public good and the role of governments and multilateral organizations in global internet governance. Meridiano 47, 19.

Chemwei, B., Kiboss, J.K. and Njag, K., 2016. Relationship between teacher-educator characteristics and the integration of Information and Communication Technologies in teaching and learning in Teacher Education Institutions in Kenya.

Davis, F.D., 1989. Perceived usefulness, perceived ease of use, and user acceptance of information technology. MIS quarterly, pp.319-340.

Dogan, M., 2010. Primary trainee teachers' attitudes to and use of computer and technology in mathematics: The case of Turkey. Educational Research and Reviews, 5(11), pp.690-702.

Fisher, M.B., Mann, B.H., Cronk, R.D., Shields, K.F., Klug, T.L. and Ramaswamy, R., 2016. Evaluating Mobile Survey Tools (MSTs) for field-level monitoring and data collection: development of a novel evaluation framework, and application to MSTs for rural water and sanitation monitoring. International journal of environmental research and public health, 13(9), p.840.

Granger, C.A., Morbey, M.L., Lotherington, H., Owston, R.D. and Wideman, H.H., 2002. Factors contributing to teachers' successful implementation of IT. Journal of computer assisted learning, 18(4), pp.480-488.

Hockly, N. and Dudeney, G., 2018. Current and future digital trends in ELT. Relc Journal, 49(2), pp.164-178. 
Hooker, M., 2017. A Study on the Implementation of the" Strengthening Innovation and Practice in Secondary Education Initiative" for the Preparation of Science, Technology, English and Mathematics (STEM) Teachers in Kenya to Integrate Information and Communication Technology (ICT) in Teaching and Learning (Doctoral dissertation, Queen's University Belfast).

ICT, 2018. Statistics. Communications Authority of Kenya. Available at: https://ca.go.ke/consumers/industryresearch-statistics/statistics/ [Accessed March 22, 2018].

ICT, 2020. Speech \& Press Release. Ministry of Information, Communications and Technology. Available at: https://ict.go.ke/downloads-2/ [Accessed April 28, 2016].

Lawrence, J.E. and Tar, U.A., 2018. Factors that influence teachers' adoption and integration of ICT in teaching/learning process. Educational Media International, 55(1), pp.79-105.

Marbán, J.M. and Mulenga, E.M., 2019. Pre-Service Primary Teachers' Teaching Styles and Attitudes towards the Use of Technology in Mathematics Classrooms. International Electronic Journal of Mathematics Education, 14(2), pp.253-263.

McAlister, M., Dunn, J. and Quinn, L., 2005. Student teachers' attitudes to and use of computers to teach mathematics in the primary classroom. Technology, Pedagogy and Education, 14(1), pp.77-105.

Michura, E.G., 2019. Sustainable Development in Education Model for Kenya Vision 2030. Journal of Education, Society and Behavioural Science, pp.1-10.

MULWA, A.S. and KYALO, D.N., 2011. The influence of ICT infrastructure on readiness to adopt e-learning in secondary schools in Kitui district, Kenya.

Peña-López, I., 2011. Measuring the WSIS Targets. A statistical framework.

Planning, N.E.P.A.D., 2012. Coordinating Agency. NEPAD agency business plan.

Rani, R. and Anisha, J., 2018. Role of ICT to enhance mathematics teaching and to raising educational standards. Internacional Journal of Scientific Research, 6(9), pp.488-490.

Ray, P.P., 2018. A survey on Internet of Things architectures. Journal of King Saud University-Computer and Information Sciences, 30(3), pp.291-319.

Sáez-López, J.M., Román-González, M. and Vázquez-Cano, E., 2016. Visual programming languages integrated across the curriculum in elementary school: A two-year case study using "Scratch" in five schools. Computers \& Education, 97, pp.129-141.

Senaviratna, N.A.M.R. and Cooray, T.M.J.A., 2019. Diagnosing Multicollinearity of Logistic Regression Model. Asian Journal of Probability and Statistics, pp.1-9.

Stronge, J.H., 2018. Qualities of effective teachers. ASCD.

Van Braak, J., Tondeur, J. and Valcke, M., 2004. Explaining different types of computer use among primary school teachers. European Journal of Psychology of Education, 19(4), p.407.

Wairiuko, J.W., 2014. Factors influencing integration of information and communication technology in teaching and learning in public secondary schools in Kenya: a case of Kajiado central sub-county (Doctoral dissertation, University of Nairobi).

Wanjala, M., 2016. Information Communication Technology Pedagogical Integration in Mathematics Instruction among Teachers in Secondary Schools in Kenya. Journal of Education and Practice, 7(2), pp.66-73.

Williamson, K., 2018. Populations and samples. In Research methods (pp. 359-377). Chandos Publishing.

World Summit on Information Society Plan of Action. 2003. Itu.int. 2003-12-12. Retrieved 2016-04-28 